\title{
Growth of pre-sprouted sugarcane seedlings submitted to supplementary lighting
}

\author{
Luiz A. Almeida Neto ${ }^{1}$, Cristiane Guiselini², Dimas Menezes², José J. F. Cordeiro Júnior ${ }^{1}$ \& \\ Héliton Pandorfi ${ }^{2}$ \\ ${ }^{1}$ Universidade Federal Rural de Pernambuco, Programa de Pós-Graduação em Engenharia Agrícola, Recife, PE, Brasil. E-mail: luizz_antonio@hotmail.com - \\ ORCID: 0000-0002-5119-244X; jairofcordeiro@hotmail.com - ORCID: 0000-0002-1138-8309 \\ ${ }^{2}$ Universidade Federal Rural de Pernambuco, Departamento de Engenharia Agrícola, Recife, PE, Brasil. E-mail: cguiseli@hotmail.com - ORCID: 0000-0003- \\ 2909-9502; dimas.menezes@ufrpe.br - ORCID: 0000-0003-2139-4259; hpandorf@hotmail.com (Corresponding author) - ORCID: 0000-0002-2037-8639
}

\begin{abstract}
Brazil is the largest producer and exporter of sugarcane in the world, and the sugar and ethanol sector has invested in the development of new technologies and methods of planting to meet the market demand. Thus, the aim of this study was to evaluate the performance of sugarcane at the acclimation phase and under field conditions, from pre-sprouted seedlings exposed to supplementary lighting, through lightemitting diode, in the period of acclimation in a greenhouse. The experiment was carried out in Carpina, PE, Brazil, from January to September 2017. The experimental plots were composed of pre-sprouted seedlings acclimated in greenhouse, exposed to the supplementary lighting systems, 90\% Red + 10\% Blue (R:B 90/10), $80 \%$ Red $+20 \%$ Blue (R:B 80/20), 70\% Red $+30 \%$ Blue (R:B 70/30) and a control. The evaluation of seedling growth was performed through the measurement of biometric indicators: plant height $(\mathrm{cm})$; stem length $(\mathrm{cm})$; stem diameter $(\mathrm{cm})$ and number of tillers. The biometric indicators showed no significant differences, but plants under lighting systems with a greater proportion of the red wavelength (R:B 80/20 and R:B 90/10) showed higher percentage of survival in the field.
\end{abstract}

Key words: Sacharum officinarum, light-emitting diode, radiation quality

\section{Crescimento de mudas pré-brotadas de cana-de-açúcar submetidas a iluminação suplementar}

RESUMO: O Brasil é o maior produtor e exportador de cana-de-açúcar do mundo e, o setor sucroenergético tem investido no desenvolvimento de novas tecnologias e métodos de plantio de cana-de-açúcar para atender à demanda do mercado. Dessa forma, objetivou-se com esta pesquisa, avaliar o desempenho de cana-açúcar no final da fase de aclimatação e em campo, proveniente de mudas pré-brotadas expostas à iluminação suplementar à base de diodo emissor de luz no período de aclimatação em ambiente protegido. O experimento foi realizado em Carpina, PE, de janeiro a setembro de 2017. As parcelas experimentais foram compostas por mudas pré-brotadas em ambiente protegido, expostas aos sistemas de iluminação suplementar, $90 \%$ vermelho $+10 \%$ azul (V:A 90/10), 80\% vermelho + 20\% azul (V:A 80/20), 70\% vermelho + 30\% azul (V:A 70/30) e o controle. A avaliação do crescimento das mudas foi realizada por meio de indicadores biométricos: altura da planta $(\mathrm{cm})$; comprimento do colmo $(\mathrm{cm})$; diâmetro do colmo $(\mathrm{cm})$ e o número de perfilhos. As variáveis biométricas não apresentaram diferenças significativas, no entanto, as plantas submetidas aos sistemas de iluminação com maior proporção do comprimento de onda vermelho (V:A 80/20 e V:A 90/10), apresentaram maior percentual de sobrevivência no campo.

Palavras-chave: Sacharum officinarum, diodo emissor de luz, qualidade de radiação 


\section{INTRODUCTION}

The increase in demand and reduction in sugar stock in the global market should sustain the production of sugarcane for the next decade, which will continue to be the main crop used for sugar manufacturing, especially in developing countries of Africa, Asia and South America.

In order to meet this growing demand, in search of higher yield, the sugar-energy sector has invested in the development of new technologies and methods of planting.

According to Gazola et al. (2017), for the sugar-energy sector to continue to advance in a sustainable manner, new seedling production techniques should be studied to make the process faster. An example is the planting of sugarcane performed with pre-sprouted seedlings, from treated minicuttings, replacing conventional planting using stems.

Throughout the growth period, the seedlings underwent the acclimation phase, in which environmental variables can be managed to obtain more resistant and vigorous seedlings. Among these variables, solar radiation has a direct influence on seedling development.

According to Souza et al. (2011), plants grown under intense radiation develop mesophilic cells rich in chloroplast, higher dry matter and higher production. However, these authors state that in addition to intensity, the quality of radiation is also determinant for these cells to develop.

In view of the above, the objective of this study was to evaluate sugarcane performance in the final phase of acclimation and in the field, grown from pre-sprouted seedlings exposed to supplementary lighting with light-emitting diode (LED) in the acclimation period in a protected environment.

\section{Material ANd Methods}

The experiment was carried out at the Estação Experimental de Cana-de-açucar do Carpina (EECAC), Universidade Federal Rural de Pernambuco, in the municipality of Carpina, PE, Brazil (7o $51^{\prime} 3^{\prime \prime} \mathrm{S}, 35^{\circ} 15^{\prime} 17^{\prime \prime} \mathrm{W}$ and altitude of $184 \mathrm{~m}$ ), from January to September 2017. The climate is characterized as, with rainfall in the winter and dry season in the summer, according to Köppen's classification (Alvares et al., 2013). The predominant soil class is Ultisol, with sandy-clay texture.

The experiment was conducted using pre-sprouted seedlings of the sugarcane variety RB92579, acclimated in a protected environment and subjected to supplementary LEDbased lighting, with light proportions of $90 \%$ red $+10 \%$ blue (R:B 90/10), 80\% red + 20\% blue (R:B 80/20), 70\% red $+30 \%$ blue (R:B 70/30), and a control, with seedlings exposed to natural solar radiation.

The experimental design adopted in the acclimation phase was the completely randomized, composed of three supplementary lighting systems and a control, which had only natural solar radiation, with five repetitions, each composed of 200 trays of 15 cells, totaling 300 seedlings.

The supplementary lighting system in the protected environment consisted of LED RGB bars, SYM-MT24RGBS-BAR-24-0.52M model, in red $(640 \mathrm{~nm})$ and blue $(470 \mathrm{~nm})$ colors, installed $0.5 \mathrm{~m}$ above the benches with trays, in wire frame, with light flux intensity adjusted to 500 lux. The bars remained turned on for $16 \mathrm{~h}$ ( $12 \mathrm{~h}$ of natural solar radiation + $4 \mathrm{~h}$ of supplementary lighting).

At the end of the acclimation phase (40 days), the seedlings were transplanted to PVC boxes, where they remained on cultivation benches under full sun for 15 days, a process known as rustication. At this stage, irrigation was performed every day, by hand, using a plastic watering can, with a water depth of $4 \mathrm{~mm}$ per day. In addition, the aerial part was pruned twice every seven days.

Soil tillage for planting the seedlings in the field was carried out 15 days before planting and consisted of harrowing (plowing harrow and leveling harrow) to break soil clods, elimination of crop residues, incorporation of limestone, systematization of the area and subsequent opening of the planting furrows. Fertilization was performed according to the management employed by EECAC, applying $12 \mathrm{~kg} \mathrm{ha}^{-1}$ of N, $24 \mathrm{~kg} \mathrm{ha}^{-1}$ of $\mathrm{P}_{2} \mathrm{O}_{5}$ and $18 \mathrm{~kg} \mathrm{ha}^{-1}$ of $\mathrm{K}_{2} \mathrm{O}$ (Cavalcanti, 2008). Sugarcane plants were grown under rainfed regime. Planting was carried out manually, with spacing of $1.5 \mathrm{~m}$ between rows and $0.5 \mathrm{~m}$ between seedlings.

In the field, the experimental plots were composed of the pre-sprouted seedlings acclimated in a protected environment, which were exposed to supplementary lighting systems, using a randomized block design with five repetitions. Each experimental plot consisted of 4 rows, with 75 plants per row.

Plant biometric analyses were performed at the end of acclimation (40 days) and at 227 days after planting in the field. Data were collected by sampling, 32 plants per treatment.

In the phase of acclimation in a protected environment, the evaluation of seedling growth considered the following biometric variables: emergence (\%), sprouting speed index; leaf area index; plant height $(\mathrm{cm})$; stem length $(\mathrm{cm})$; stem diameter $(\mathrm{cm})$; and root length $(\mathrm{cm})$.

Root volume $\left(\mathrm{mm}^{3}\right)$ was obtained by the displacement of water volume in a graduated cylinder. The root system was dried in an oven at $60{ }^{\circ} \mathrm{C}$ until reaching constant weight, then root dry matter $(\mathrm{g})$ was determined.

The contents of total soluble carbohydrates and sucrose were determined according to the methodology described by Bezerra Neto \& Barreto (2011), in which one curve was obtained by standard glucose solution for the total soluble carbohydrate content and another curve was obtained by standard sucrose solution for sucrose content, at the respective concentrations of 25, 50, 100 and $200 \mathrm{mg} \mathrm{L}^{-1}$.

Measurements were taken as follows: stem diameter $(\mathrm{cm})$ with a digital caliper at $20 \mathrm{~cm}$ height from the base; plant height $(\mathrm{m})$ with a tape measure from the collar to the inflection point of the +1 leaf; stem length $(\mathrm{cm})$ with a tape measure from the collar of the plant to the last visible stem, and number of tillers per plant, by counting (Oliveira et al., 2016). The number of dead plants was counted and the survival percentages of seedlings (45 DAP) and plants until the beginning of maturation (227 DAP) were calculated.

The experimental period was meteorologically characterized using data of air temperature $\left({ }^{\circ} \mathrm{C}\right)$, air relative humidity (\%), rainfall $(\mathrm{mm})$ and global solar radiation $\left(\mathrm{MJ} \mathrm{m}^{-2} \mathrm{~d}^{-1}\right)$, from the meteorological station of the Agência Pernambucana de Águas e Clima (APAC), installed at the EECAC.

The data were subjected to analysis of variance and the means were compared by Tukey test ( $\mathrm{p} \leq 0.05)$, using SISVAR software, version 5.6 (Ferreira, 2011). 


\section{Results AND Discussion}

Higher values of emergence percentage and sprouting speed index were found in seedlings subjected to the control $(64.00 \%$ and $2.96)$, compared to the supplementary lighting system $R: B$ 80/20 (61.87\% and 2.82), but these treatments did not show significant difference (Table 1). In addition to the environmental factors, variety, age, health of buds and management adopted in the planting can affect the sprouting process (Manhães et al., 2015). In this stage of seedling development, the effect of solar radiation has low influence on the development of sugarcane buds; therefore, the different LED lighting systems had little influence during this period, due to the low photosynthetic activity of the seedlings.

In regard to the biometric variables plant height and stem length, higher mean values were observed in the R:B 80/20 system, equal to 48.68 and $12.59 \mathrm{~cm}$, respectively, being significantly higher compared to R:B 90/10. Elia (2016) found pre-sprouted seedling height of $39.4 \mathrm{~cm}$ at 51 days after planting in the field. Silva et al. (2014), evaluating different wavelength combinations in in-vitro cultivation of sugarcane under LEDbased lighting, observed that seedlings grown under a higher proportion of red were taller.

For stem diameter, there was no significant response between the lighting systems studied, with values ranging from 0.43 (R:B 90/10) to $0.47 \mathrm{~cm}$ (R:B 80/20). Cristofoletti Junior (2012) evaluated the emergence of mini-cuttings of nine sugarcane varieties and observed values of plant diameter ranging from 4.45 to $4.89 \mathrm{~cm}$, at 48 DAP. The LAI of the seedlings subjected to supplementary lighting systems (R:B 80/20, R:B 90/10 and R:B $70 / 30$ ) were higher $(4.73,3.72$ and 4.14$)$, but only the R:B 80/20 system differed significantly from the control (3.34).

The highest content of total carbohydrates $\left(\mathrm{CH}_{\text {total }}\right)$ was observed in the control $\left(130.29 \mathrm{mg} \mathrm{L}^{-1}\right)$, which showed significant difference when compared to the supplementary lighting systems (R:B 80/20, R:B 90/10 and R:B 70/30). There was lower $\mathrm{CH}_{\text {total }}$ in the R:B $90 / 10$ system $\left(86.43 \mathrm{mg} \mathrm{L}^{-1}\right.$ ). For sucrose, supplementary lighting did not show significant difference.

The use of supplementary lighting caused no significant effect on root dry matter (RDM), root length (RL) and root volume (RV). These results are similar to those observed by Ferreira et al. (2017), who did not find significant differences for root length after the acclimation period of sugarcane exposed to LED lighting in in-vitro cultivation.

Elia (2016) obtained root length of $11.3 \mathrm{~cm}$ for pre-sprouted sugarcane seedlings cultivated without irrigation, at 51 days after planting in the field. According to Silva et al. (2016), the effects of light spectrum quality on root dry matter production, in general, are still contradictory and inconclusive.

Figure 1 shows the daily mean variation of rainfall and global solar radiation $(\mathrm{Rg})$ along the period. The total rainfall in the period was $932.2 \mathrm{~mm}$. The highest values of monthly

Table 1. Values of the biometric variables of the seedlings at the end of the acclimation phase (40 days after emergence - DAE), for different supplementary lighting systems

\begin{tabular}{|c|c|c|c|c|c|}
\hline \multirow{2}{*}{ Biometric variables } & \multicolumn{5}{|c|}{ Supplementary lighting systems } \\
\hline & R:B 80/20 & R:B 90/10 & R:B 70/30 & Control & CV (\%) \\
\hline Emergence (\%) & $61.87 \mathrm{a}$ & $42.40 \mathrm{~b}$ & $44.00 \mathrm{~b}$ & $64.00 \mathrm{a}$ & 14.40 \\
\hline Sprouting speed index & $2.82 \mathrm{a}$ & $1.91 \mathrm{~b}$ & $2.06 \mathrm{~b}$ & $2.96 \mathrm{a}$ & 13.72 \\
\hline Plant height (cm) & $48.68 \mathrm{a}$ & $44.20 \mathrm{~b}$ & $45.62 \mathrm{ab}$ & $47.26 a b$ & 4.16 \\
\hline Stem length (cm) & $12.59 \mathrm{a}$ & $11.32 b$ & $11.51 \mathrm{ab}$ & $12.01 \mathrm{ab}$ & 5.08 \\
\hline Stem diameter $(\mathrm{cm})$ & $0.47 a$ & $0.43 \mathrm{a}$ & $0.44 \mathrm{a}$ & $0.45 \mathrm{a}$ & 5.65 \\
\hline Leaf area index - LAI & $4.73 \mathrm{a}$ & $3.72 \mathrm{ab}$ & 4.14. $a b$ & $3.34 b$ & 14.06 \\
\hline Total carbohydrates $-\mathrm{CH}_{\text {total }}\left(\mathrm{mg} \mathrm{L}^{-1}\right)$ & $103.44 \mathrm{~b}$ & $86.43 \mathrm{C}$ & $109.78 b$ & $130.29 \mathrm{a}$ & 8.69 \\
\hline Sucrose - SUC $\left(\mathrm{mg} \mathrm{L}^{-1}\right)$ & $178.38 \mathrm{a}$ & $145.87 \mathrm{a}$ & $187.71 \mathrm{a}$ & $206.36 \mathrm{a}$ & 24.22 \\
\hline Root dry matter - RDM (g) & $0.197 \mathrm{a}$ & $0.210 \mathrm{a}$ & $0.229 \mathrm{a}$ & $0.238 \mathrm{a}$ & 18.25 \\
\hline Root length - RL (cm) & $15.18 \mathrm{a}$ & $14.16 \mathrm{a}$ & $14.27 \mathrm{a}$ & $15.32 \mathrm{a}$ & 8.78 \\
\hline Root volume - RV $\left(\mathrm{cm}^{3}\right)$ & $7.0 \mathrm{a}$ & $10.0 \mathrm{a}$ & $8.0 \mathrm{a}$ & $7.0 \mathrm{a}$ & 30.19 \\
\hline
\end{tabular}

R:B 80/20 - 80\% Red + 20\% Blue; R:B 90/10 - 90\% Red + 10\% Blue; R:B 70/30 - 70\% Red + 30\% Blue; Control - Seedling exposed to natural solar radiation; Means followed by the same letter in the row do not differ by Tukey test $(\mathrm{p} \leq 0.05)$

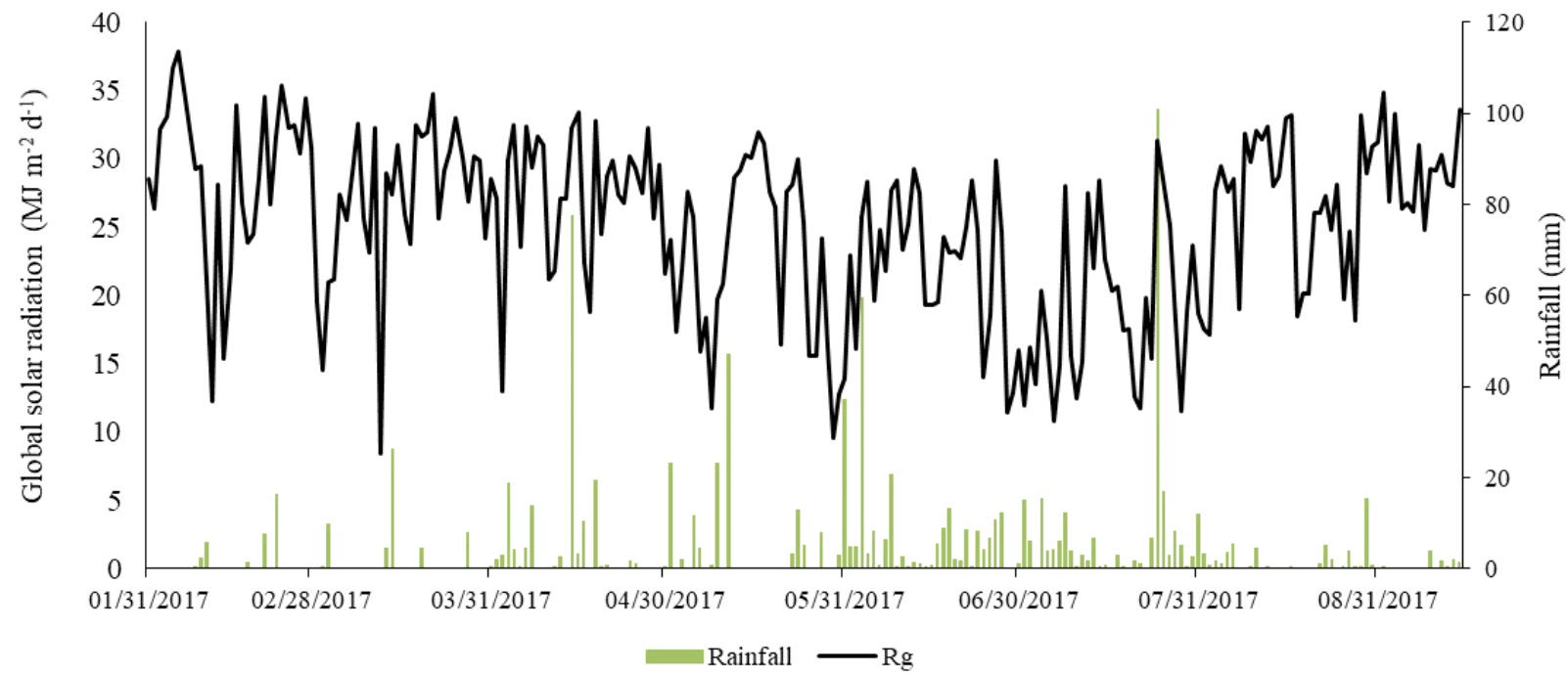

Figure 1. Daily variation of rainfall and global solar radiation $(\mathrm{Rg})$ along the experimental period 
rainfall occurred between May and July, which corresponded to $65.4 \%$ of the total accumulated along the period evaluated. The lowest monthly rainfall occurred in February $(33.5 \mathrm{~mm})$.

According to Meneses \& Resende (2016), one of the main factors affecting sugarcane yield in the Coastal Tablelands of Northeast Brazil, consists of the irregular distribution of rainfall, so it is necessary to manage the crop so that the periods of highest water demand, such as the vegetative growth stage, coincide with the highest availability of water in the soil. In the present study, the period of planting the seedlings coincided with the month of lowest rainfall. The period of sugarcane planting is one of the most relevant aspects to have good final yield or good stand of seedlings.

The average global solar radiation $(\mathrm{Rg})$ was $25.11 \mathrm{MJ} \mathrm{m}^{-2} \mathrm{~d}^{-1}$, with minimum of $8.44 \mathrm{MJ} \mathrm{m}^{-2} \mathrm{~d}^{-1}$ and maximum of $37.85 \mathrm{MJ} \mathrm{m}^{-2}$ $\mathrm{d}^{-1}$. The month of February had the highest monthly average of $\operatorname{Rg}\left(29.18 \mathrm{MJ} \mathrm{m}^{-2} \mathrm{~d}^{-1}\right)$ (Figure 1). In the vegetative development stage, processes that depend on solar radiation, such as tillering, are favored by intense solar radiation (Marin et al., 2009).

The lowest monthly average values of $\mathrm{Rg}$ were observed in May and July, with values of 22.55 and $18.95 \mathrm{MJ} \mathrm{m}^{-2} \mathrm{~d}^{-1}$, respectively. For good growth and development of the crop, days with average global solar radiation above $18 \mathrm{MJ} \mathrm{m}^{-2} \mathrm{~d}^{-1}$ are necessary. Solar radiation is the main environmental variable influencing dry matter accumulation, when the requirements of water, nutrients and health are met (Ferreira Júnior et al., 2014). Araújo et al. (2017) found that the highest number of tillers occurred in production environments with higher incidence of solar radiation in the initial stage of the crop.

Radiation is one of the most important factors for sugarcane tillering, because the incidence of solar radiation at the base of the plant in this period activates basal vegetative buds. In the case of low intensity of solar radiation, tillering would be decreased or ceased (Jadoski et al., 2010). The intensity and quality of solar radiation inside the canopy influence the physiological processes of plants, hence directly affecting production (Brunini \& Turco, 2016).

The average daily air relative humidity $(\mathrm{RH}, \%)$ observed in the period was $80.7 \%$. The minimum daily $\mathrm{RH}$ was observed in February (66\%) and the maximum RH was found in May (94.6\%) (Figure 2).
The average air temperature (Tair, ${ }^{\circ} \mathrm{C}$ ) along the experimental period ranged from 21.2 to $27.7^{\circ} \mathrm{C}$, with daily average of $24.6^{\circ} \mathrm{C}$ (Figure 2). Oliveira et al. (2011), in a study conducted in the municipality of Carpina, PE, Brazil, found an average annual temperature higher than $25^{\circ} \mathrm{C}$. The highest values of Tair were observed in February and March (26.6 and $26.5^{\circ} \mathrm{C}$ ). Conversely, the lowest value was recorded in July, with an average Tair of $22.2^{\circ} \mathrm{C}$. It can be noted that, during the studied period, Tair was not a restrictive factor for sugarcane growth and remained within the range $\left(20-30{ }^{\circ} \mathrm{C}\right)$ considered optimal for its development in the field; with values below 16 ${ }^{\circ} \mathrm{C}$ and above $38^{\circ} \mathrm{C}$, its growth would become null (Marin et al., 2009).

Table 2 shows the percentage of survival (\%S) of seedlings in the field at 45 and 227 days after planting (DAP). Plants grown from seedlings subjected to supplementary LED lighting systems R:B 80/20 and R:B 90/10 had higher survival percentage ( $\mathrm{p} \leq 0.05$ ) compared to the R:B 70/30 system and the control, at 45 DAP. Rocha et al. (2013) found that seedlings grown in vitro under red LEDs showed higher percentage of survival when transplanted to the acclimation phase. Among the supplementary lighting systems in the present study, the R:B 80/20 stood out, as it had survival percentage of $90.91 \%$. At the end of the experimental period (227 DAP), there was a reduction in the percentage of survival of the plants at the beginning of maturation, formed from seedlings subjected to supplementary lighting systems, among which the R:B 80/20 system showed higher survival percentage $(72.87 \%)$, followed

Table 2. Values of the number of dead plants (NDP) and percentage of survival $(\% \mathrm{~S})$ at 45 and 227 days after planting (DAP)

\begin{tabular}{ccccc|}
\hline & \multicolumn{2}{c}{ 45 DAP } & \multicolumn{2}{c|}{ 227 DAP } \\
\cline { 2 - 5 } & NDP & $\%$ S & NDP & $\% S$ \\
\hline R:B 80/20 & $27.27 \mathrm{a}$ & $90.91 \mathrm{a}$ & $81.39 \mathrm{a}$ & $72.87 \mathrm{a}$ \\
R:B 90/10 & $36.84 \mathrm{a}$ & $87.72 \mathrm{a}$ & $96.51 \mathrm{a}$ & $67.83 \mathrm{a}$ \\
R:B 70/30 & $71.79 \mathrm{a}$ & $76.07 \mathrm{~b}$ & $112.80 \mathrm{a}$ & $62.40 \mathrm{a}$ \\
Control & $51.84 \mathrm{a}$ & $82.72 \mathrm{~b}$ & $112.14 \mathrm{a}$ & $62.62 \mathrm{a}$ \\
CV (\%) & 9.06 & 11.92 & 10.35 & 13.40 \\
\hline
\end{tabular}

R:B 80/20 - 80\% Red + 20\% Blue; R:B 90/10 - 90\% Red + 10\% Blue; R:B 70/30 - 70\% Red $+30 \%$ Blue; Control - Seedling exposed to natural solar radiation; Means followed by the same letter in the column do not differ significantly by Tukey test at $\mathrm{p} \leq 0.05$

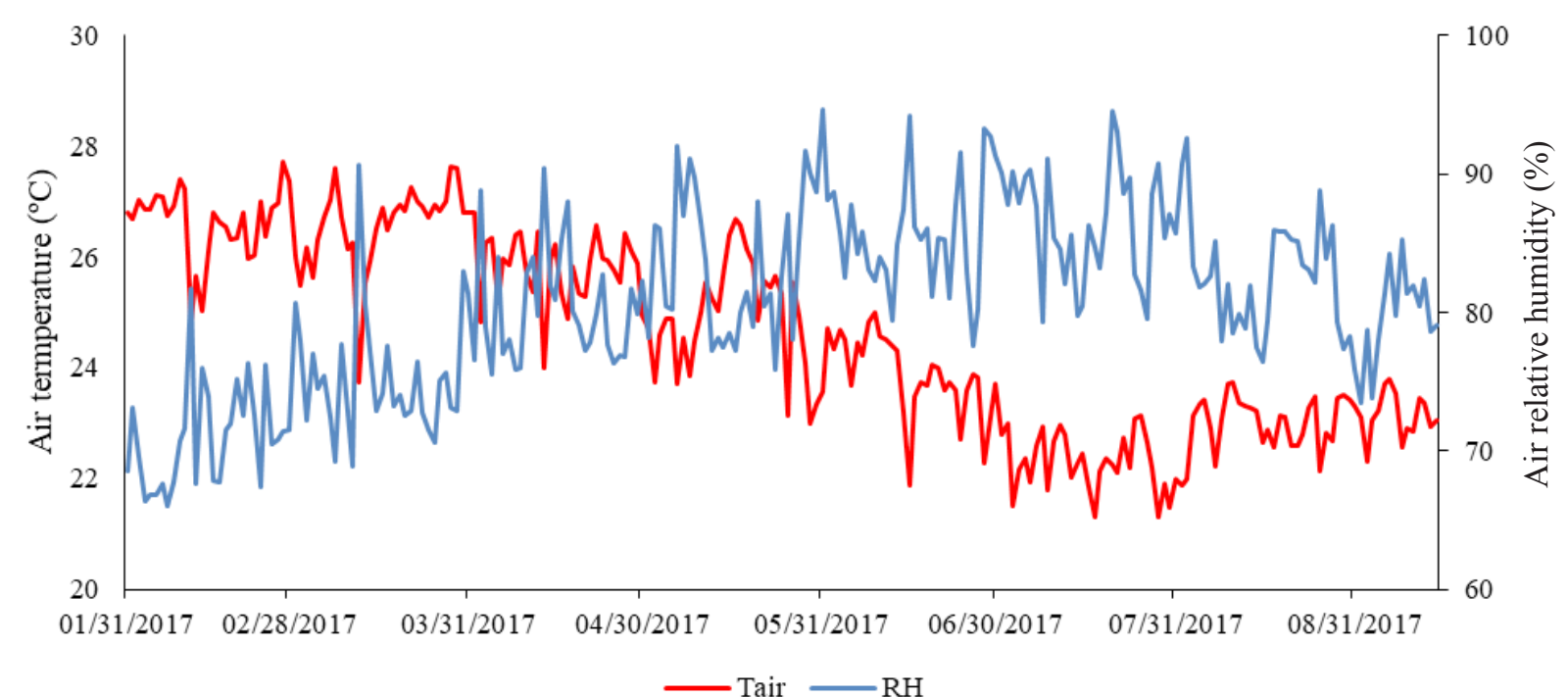

Figure 2. Daily variation of air relative humidity $(\mathrm{RH})$ and air temperature (Tair) along the experimental period 
by $\mathrm{R}: \mathrm{B} 90 / 10$ (67.83\%), with the lowest values in $\mathrm{R}: \mathrm{B} 70 / 30$ $(62.40 \%)$ and in the control (62.62) (Table 2). Elia (2016) found total mortality of $37.9 \%$ at 156 DAP in pre-sprouted seedlings cultivated without irrigation. The author emphasizes the importance of irrigation immediately after planting to ensure the establishment of seedlings.

Plants subjected to lighting systems with higher proportion of red wavelength (R:B 80/20 and R:B 90/10) had the highest $\%$ S. Ferreira et al. (2017), when studying the effects of LED lighting on sugarcane acclimation in in-vitro cultivation, found that plants grown under LEDs ( $82 \%$ red and 18\% blue) increased the percentage of survival after being transplanted. The spectrum in the red range is close to the peaks of maximum light absorption of chlorophyll and phytochromes; for this reason, it becomes important for the photosynthetic apparatus for accumulation of carbohydrates and increase in the development of shoots (Rocha et al., 2010).

Table 3 shows data of biometric variables evaluated at 227 DAP. For all variables studied, there were no significant differences between plants grown from seedlings associated with supplementary LED lighting systems and the control. The values of $\mathrm{PH}$ and SD obtained in this study are higher than those found by Oliveira et al. (2014), 224.67 and $2.65 \mathrm{~cm}$, respectively, for sugarcane cut at 11 months.

Kim et al. (2004) point out that morphological or physiological adaptations are likely to occur in leaves when exposed to different types of lighting along growth, and such adaptations confuse the interpretation of single spectral effects.

The effects that each specific wavelength causes on sugarcane development, as well as its interaction with other meteorological variables, are complex and vary according to the cultivation environment, development stage and variety.

Although in the acclimation phase the supplementary lighting system R:B 80/20 resulted in greater growth of the seedlings, there were no significant differences in the field. Oliveira et al. (2014) in a study with different sugarcane cultivars concluded that the biometric variables plant height and diameter were the ones that most influenced the calculation of yield $(\mathrm{TCH}$, $\mathrm{t} \mathrm{ha}^{-1}$ ). For Lin et al. (2013), the yield and quality of the plants are the result of interactions between various environmental factors under which plants are grown.

Table 3. Values of sugarcane biometric variables: plant height $(\mathrm{PH})$, stem length (SL), stem diameter (SD) and number of tillers (NT) at 227 days after planting (DAP)

\begin{tabular}{ccccc} 
& \multicolumn{4}{c}{ 227 DAP } \\
\cline { 2 - 4 } & PH & SL & SD & NT \\
\cline { 2 - 4 } R:B 80/20 & $327.26 \mathrm{a}$ & $214.46 \mathrm{a}$ & $2.73 \mathrm{a}$ & $8.2 \mathrm{a}$ \\
$\mathrm{R}: \mathrm{B} 90 / 10$ & $316.66 \mathrm{a}$ & $214.86 \mathrm{a}$ & $2.60 \mathrm{a}$ & $7.5 \mathrm{a}$ \\
$\mathrm{R}: \mathrm{B} 70 / 30$ & $289.26 \mathrm{a}$ & $183.80 \mathrm{a}$ & $2.50 \mathrm{a}$ & $7.2 \mathrm{a}$ \\
Control & $299.33 \mathrm{a}$ & $191.46 \mathrm{a}$ & $2.55 \mathrm{a}$ & $6.9 \mathrm{a}$ \\
$\mathrm{CV}(\%)$ & 9.33 & 15.57 & 5.94 & 20.14 \\
\hline
\end{tabular}

R:B 80/20 - 80\% Red + 20\% Blue; R:B 90/10 - 90\% Red + 10\% Blue; R:B 70/30 - 70\% Red $+30 \%$ Blue; Control - Seedling exposed to natural solar radiation

\section{Conclusions}

1. The dichromatic LED-based supplementary lighting systems $80 \%$ red $+20 \%$ blue and $90 \%$ red $+10 \%$ blue led to seedlings with higher percentage of plant survival in the field, but without significant responses in terms of biometric variables.

2. The biometric responses of the seedlings at the end of the acclimation phase did not result in plant growth at 227 days after planting.

\section{Literature Cited}

Alvares, C. A.; Stape, J. L.; Sentelhas, P. C.; Gonçalves, J. L. de Moraes; Sparovek, G. Köppen's climate classification map for Brazil. Meteorologische Zeitschrift, v.22, p.711-728, 2013. https:// doi.org/10.1127/0941-2948/2013/0507

Araújo, R. M.; Oliveira, R. A. de; Cuadra, S. V.; Almeida, I. R. de; Weber, H. Condições agrometeorológicas para perfilhamento máximo da cultura de cana-de-açúcar em dois ambientes distintos de produção. Agrometeoros, v.25, p.257-264, 2017. https://doi. org/10.31062/agrom.v25i1.26287

Bezerra Neto, E.; Barreto, L. P. Análises químicas e bioquímicas em plantas. Recife: UFRPE, 2011. 161p.

Brunini, R. G.; Turco, J. E. P. Crescimento da cana-de-açúcar (Sacharum ssp L.) em diferentes cenários produtivos de exposições e declividades. Ambiência, v.12, p.841-849, 2016.

Cavalcanti, F. J. A. Recomendações de adubação para o Estado de Pernambuco: $2^{\text {a }}$ aproximação. 3. ed. Recife: IPA, 2008. 212p.

Cristofoletti Junior, S. C. Fisiologia da emergência e perfilhamento em mini-toletes de variedades de cana. Piracicaba: ESALQ/USP, 2012. 92p. Dissertação Mestrado

Elia, P. Estabelecimento e desenvolvimento de mudas pré-brotadas de cana-de-açúcar sob diferentes lâminas de irrigação. Piracicaba: ESALQ/USP, 2016. 88p. Dissertação Mestrado

Ferreira, D. F. Sisvar: A computer statistical analysis system. Ciência e Agrotecnologia, v.35, p.1039-1042, 2011. https://doi. org/10.1590/S1413-70542011000600001

Ferreira, L. T.; Silva, M. M. de A.; Ulisses, C.; Camara, T. R.; Willadino, L. Using LED lighting in somatic embryogenesis and micropropagation of an elite sugarcane variety and its effect on redox metabolism during acclimatization. Plant Cell, Tissue and Organ Culture, v.128, p.211-221, 2017. https://doi.org/10.1007/ s11240-016-1101-7

Ferreira Junior, R. A.; Souza, J. L. de; Teodoro, I.; Lyra, G. B.; Souza, R. C. de; Araújo Neto, R. A. de. Eficiência do uso da radiação em cultivos de milho em Alagoas. Revista Brasileira de Engenharia Agrícola e Ambiental, v.18, p.322-328, 2014. https://doi. org/10.1590/S1415-43662014000300012

Gazola, T.; Cipola Filho, M. L.; Franco Júnior, N. C. Avaliação de mudas pré-brotadas de cana-de-açúcar provenientes de substratos submetidos a adubação química e orgânica. Científica, v.45, p.300-306, 2017. https://doi.org/10.15361/19845529.2017v45n3p300-306

Jadoski, C. J; Toppa, E. V. B.; Julianetti, A.; Hulshof, T.; Ono, E. O; Rodrigues, J. D. Fisiologia do desenvolvimento de estádio vegetativo da cana-de-açúcar (Saccharum officinarum L.). Pesquisa Aplicada e Agrotecnologia, v.3, p.169-186. 2010.

Kim, H. H.; Goins, G. D.; Wheeler, R. M.; Sager, J. C. Stomatal conductance of lettuce grown under or exposed to different light qualities. Annals of Botany, v.94, p.691-697, 2004. https://doi. org/10.1093/aob/mch192 
Lin, K. H.; Huang, M. Y.; Huang, W. D.; Hsu, M. H.; Yang, Z. W.; Yang, C. M. The effects of red, blue, and white light-emitting diodes on the growth, development, and edible quality of hydroponically grown lettuce (Lactuca sativa L. var. capitata). Scientia Horticulturae, v.150, p.86-91, 2013. https://doi.org/10.1016/j. scienta.2012.10.002

Manhães, C. M. C.; Garcia, R. F.; Francelino, F. M. A; Francelino, H. O.; Coelho, F. C. Fatores que afetam a brotação e o perfilhamento da cana-de-açúcar. Vértices, v.17, p.163-181, 2015. https://doi. org/10.5935/1809-2667.20150011

Marin, F. R.; Pellegrino, G. Q.; Assad, E. D.; Pinto, H. S.; Zullo Júnior, J. Agrometeorologia da cana-de-açúcar. In: Monteiro, J. E. B. A. (org.). Agrometeorologia dos cultivos: Levantamento sistemático de informações agrometeorológicas e fitotécnicas. Brasília: INMET, 2009. p.109-130.

Meneses, T. N.; Resende, R. S. Influência de épocas de plantio na eficiência do uso da água da chuva em cultivo irrigado de canade-açúcar. Brazilian Journal of Irrigation and Drainage, v.1, p.291305, 2016. https://doi.org/10.15809/irriga.2016v1n1p291-305

Oliveira, A. R. de; Braga, M. B.; Santos, B. L. S.; Walker, A. M. Análise biométrica de cultivares de cana-de-açúcar cultivadas sob estresse hídrico no vale do submédio São Francisco. Energia na Agricultura, v.31, p.48-58, 2016. https://doi.org/10.17224/ EnergAgric.2016v31n1p48-58

Oliveira, E. C. A. de; Freire, F. J.; Oliveira, R. I. de; Oliveira, A. C. de; Freire, M. B. G. dos S. Acúmulo e alocação de nutrientes em canade-açúcar. Revista Ciência Agronômica, v.42, p.579-588, 2011.
Oliveira, M. P.; Ragghianti, K. C.; Homem, B. F. M.; Marques, M. O. Cana-de-açúcar: Análise biométrica de cultivares, ano agrícola 2012/2013. Ciência \& Tecnologia, v.6, p.110-114, 2014.

Rocha, P. S. G. da; Oliveira, R. P. de; Scivittaro, W. B. Sugarcane micropropagation using light emitting diodes and adjustment in growth-medium sucrose concentration. Ciência. Rural, v.43, p.11681173, 2013. https://doi.org/10.1590/S0103-84782013000700005

Rocha, P. S. G. da; Oliveira, R. P. de; Scivittaro, W. B.; Santos, U. L. D. Diodos emissores de luz e concentrações de BAP na multiplicação in vitro de morangueiro. Ciência Rural, v.40, p.1922-1928, 2010. https://doi.org/10.1590/S0103-84782010000900011

Silva, E. M. da; Costa, G. G. S. da; Andrade, A. F.; Ferreira, H. C. P.; Steiner, F. Produção de mudas de alface, pepino e pimentão em função da qualidade do espectro luminoso. Scientia Agraria Paranaensis, v.15, p.446-452, 2016.

Silva, M. M. de A.; Oliveira, A. L. de; Oliveira Filho, R. A.; Gouveia Neto, A. S.; Camara, T. J.; Willadino, L. G. Effect of blue/red LED light combination on growth and morphogenesis of Saccharum officinarum plantlets in vitro. In: Imaging, Manipulation, and Analysis of Biomolecules, Cells, and Tissues, 12, 2014, São Francisco. Proceedings... São Francisco: SPIE, 2014. https://doi. org/10.1117/12.2036200

Souza, G. S. de; Castro, E. M. de; Soares, Â. M.; Santos, A. R. dos; Alves, E. Photosynthetic pigments content, photosynthesis rate and chloroplast structure in young plants of Mikania laevigata Schultz Bip. ex Baker grown under colored nets. Semina: Ciências Agrárias, v.32, p.1843-1854, 2011. https://doi.org/10.5433/16790359.2011v32Suplp1843 